\title{
Performance evaluation and comparison of diode clamped multilevel inverter and hybrid inverter based on PD and APOD modulation techniques
}

\author{
N. Susheela, P. Satish Kumar \\ Department of Electrical Engineering, Osmania University, India
}

\begin{tabular}{l} 
Article Info \\
\hline Article history: \\
Received Aug 29, 2018 \\
Revised Apr 1, 2019 \\
Accepted May 8, 2019 \\
\hline Keywords: \\
Diode clamped multilevel \\
inverter \\
Hybrid inverter \\
Sinusoidal pulse width \\
modulation \\
Total harmonic distortion
\end{tabular}

\begin{abstract}
The popularity of multilevel inverters have increasing over the years in various applications without use of a transformer and has many benefits. This work presents the performance and comparative analysis of single phase diode clamped multilevel inverter and a hybrid inverter with reduced number of components. As there are some drawbacks of diode clamped multilevel inverter such as requiring higher number of components, PWM control method is complex and capacitor voltage balancing problem, an implementation of hybrid inverter that requires fewer components and less carrier signals when compared to conventional multilevel inverters is discussed. The performance of single phase diode clamped multilevel inverter and hybrid multilevel inverter for seven, nine and eleven levels is performed using phase disposition, alternate phase opposition disposition sinusoidal pulse width modulation techniques. Both the multilevel inverter are implemented for the above mentioned multicarrier based Pulse Width Modulation methods for $\mathrm{R}$ and R-L loads. The total harmonic distortion is evaluated at various modulation indices. The analysis of the multilevel inverters is done by simulation in matlab/simulink environment.
\end{abstract}

Copyright (C) 2019 Institute of Advanced Engineering and Science. All rights reserved.

\section{Corresponding Author:}

N. Susheela, Department of Electrical Engineering, University College of Engineering, Osmania University, Hyderabad, Telangana, India. Email: nsusheela2007@yahoo.com

\section{INTRODUCTION}

The multilevel inverter (MLI) is now proven technology for medium/high voltage high- power applications such as such as marine drives, variable-speed drives, reactive power compensation, steel rolling mills and other applications. The concept of power conversion in multilevel inverters (MLI) is to synthesize a staircase voltage waveform from several lower voltage DC sources which approaches the sinusoidal wave with reduced harmonic distortion has got several advantages and have drawn tremendous interest in high power high voltage applications [1-4]. In case of multilevel inverters the semiconductors are wired to form series type connection so that the operation at higher voltages is possible. The switching losses and the switching frequency can be reduced by staggering the switching because the switches are not truly series connected. Conventional multilevel inverters include neutral point clamped (diode-clamped) inverter, flying capacitor (capacitor clamped) inverter and cascaded $\mathrm{H}$-bridge inverter. The major drawback of multilevel inverters is the 
higher number of power semiconductor switches needed that complicates the overall system [5-8]. Using lower rated switches in the multilevel inverter can reduce the cost of active semiconductors compared to two level inverters. Associated gate drive circuits are required for each active semiconductor which increases the complexity. In [9], the symmetrical topology which is called as reversing voltage topology is implemented for single phase seven level inverter using phase disposition method. This multilevel inverter topology requires less number of components when compared to conventional multilevel inverters. A multilevel inverter with reversing voltage component has many advantages as the levels increase when compared to conventional multilevel inverters. The hybrid topology eliminates the diodes and capacitors that are used in diode clamped inverters, capacitors used in flying capacitor inverters and also reduces the switches and carrier signals required than in cascaded inverters, diode clamped, and flying capacitors inverters. An approach of utilizing high-power devices with low-switching-frequency reduces voltage distortion of output but has got current harmonics which is a major drawback [10-13]. There are asymmetrical methods of using different values of voltage source which requires more number of power switches and diodes with different rating. Some topologies suffer from the capacitor balancing problems. Whereas in case of hybrid MLI, the voltage sources used have equal values and has many advantages compared with the methods discussed above. It utilizes less number of switches and carriers and also operates the switching devices at line frequency. The different multicarrier PWM methods are reported to minimize total harmonic distortion (THD). Advanced MLI topologies have been proposed recently such as hybrid multilevel inverter, soft switching inverter and generalized MLI. These are extensively used in applications like FACTS, tractions and industrial drives [14-19]. The phase disposition (PD) and alternate phase opposition disposition (APOD) sinusoidal pulse width modulation (SPWM) methods are used to drive the single phase DCMLI and hybrid MLI for different levels. The general MLI inverter structure for various levels is shown in in Figure 1.

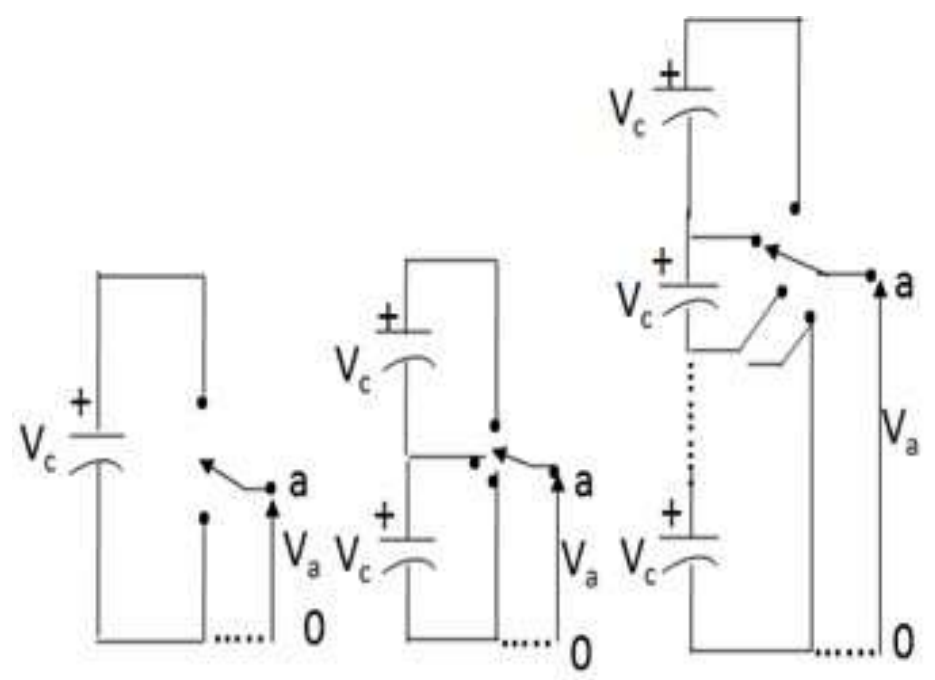

Figure 1. MLI inverter structure for two, three and n-levels

\section{MULTILEVEL INVERTERS}

The analysis of diode clamped multilevel inverter and hybrid inverter are discussed based on sinusoidal pulse width modulation techniques.

\subsection{Diode clamped MLI}

In order to generate seven levels by SPWM, six carriers and a sinusoidal reference signal for modulator are needed for DCMLI. The arrangement of the carriers for APOD and PD techniques can be seen in Figure 2 and Figure 3.

Int. J. of Adv. in Appl. Sci. Vol. 8, No. 2, June 2019: 143 - 153 


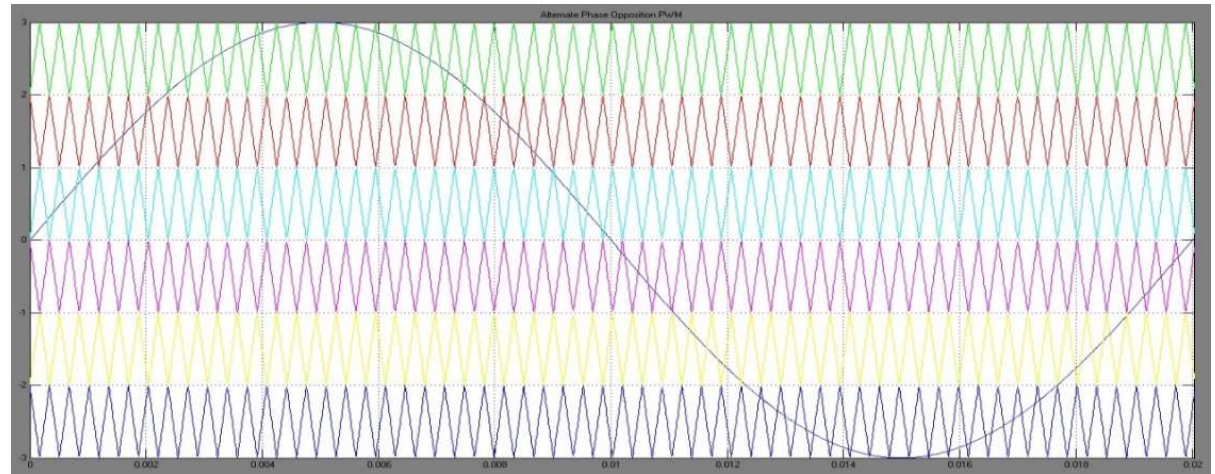

Figure 2. APOD PWM technique for single phase 7 level DCMLI

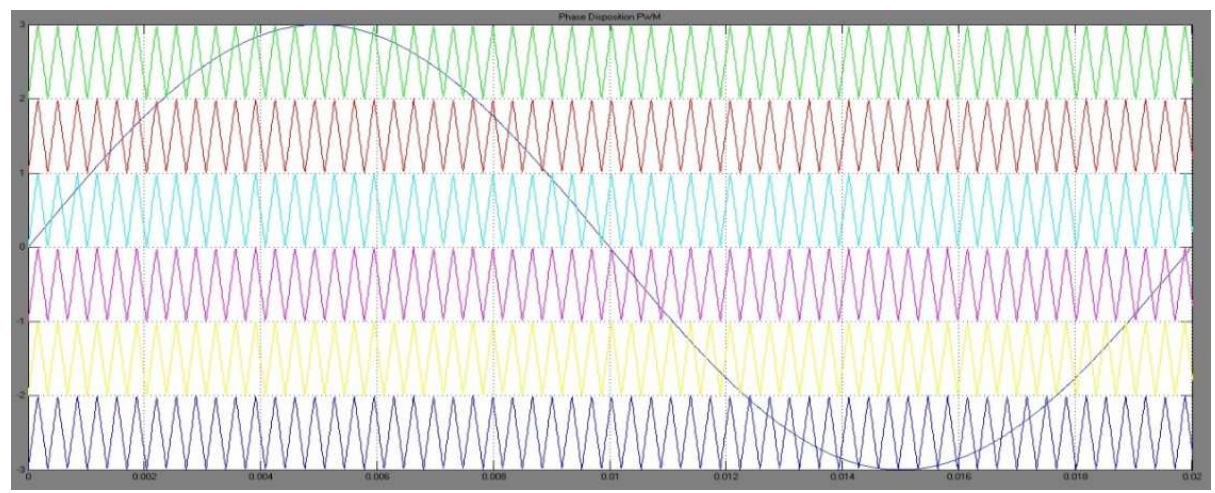

Figure 3. PD PWM technique for single phase 7 level DCMLI

\subsection{Hybrid MLI}

The hybrid MLI has two stages in which one stage is level generation and other is polarity generation stage. The first stage requires high-frequency switches which produces the required positive levels. The output polarity can be obtained by the second stage that has low frequency switches. The hybrid MLI eliminates higher number switches that are required to generate output levels. The single phase 7 level DCMLI usiing SPWM requires 6 carriers, but three carriers are sufficient for hybrid MLI. The 7 level hybrid MLI requires only 3 carriers and a sinusoidal reference. Figure 4 and Figure 5 represents the carrier arrangement using APOD and PD SPWM techniques.

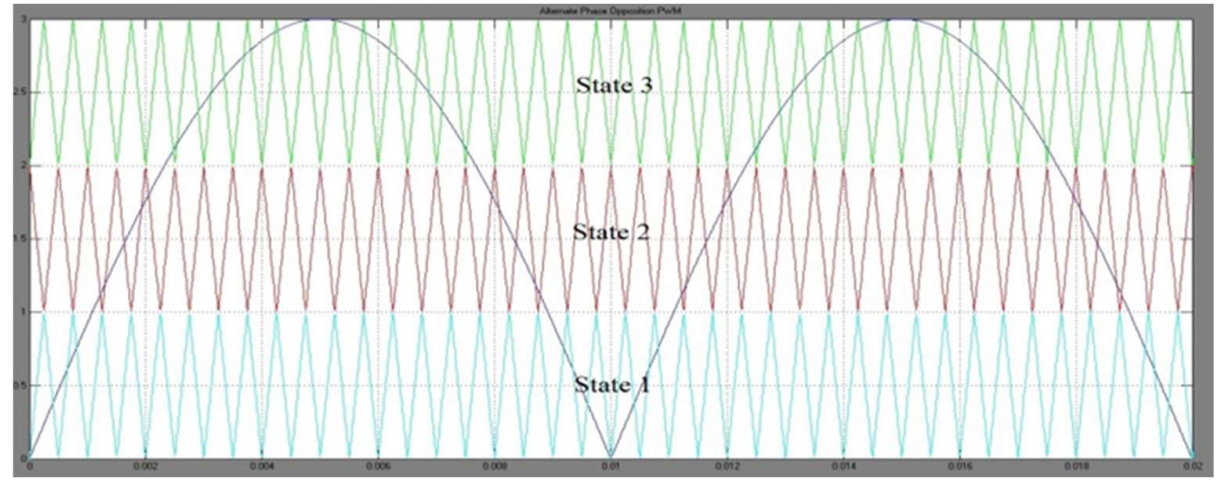

Figure 4. APOD PWM technique for single phase 7 level hybrid inverter 


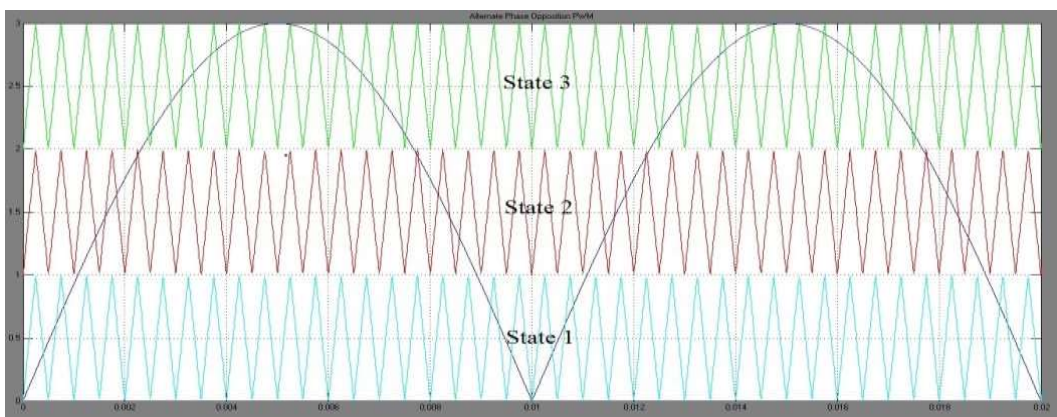

Figure 5. PD PWM technique for single phase 7 level hybrid inverter

\section{IMPLEMENTATION OF DCMLI AND HYBRID MLI}

Figure 6 and Figure 7 depicts the simulation models for producing gating signals in a single phase 7 level DCMLI using APOD and PD SPWM techniques.

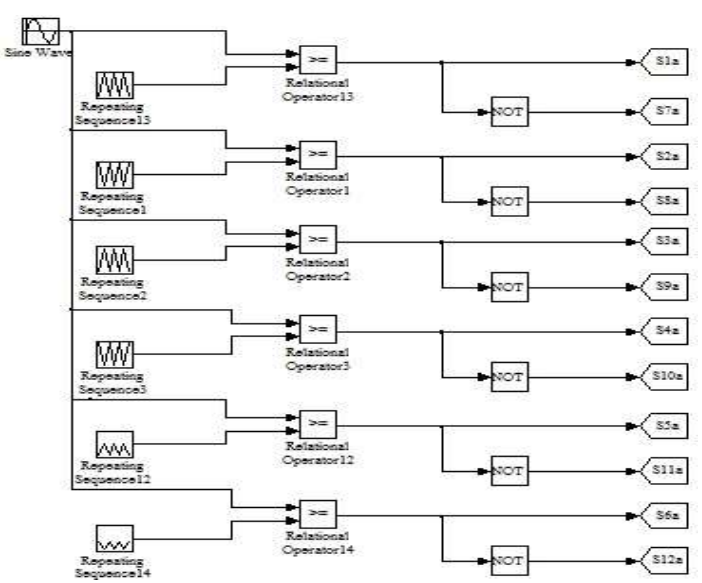

Figure 6. Model for gating signals of 7 level DCMLI using APOD method

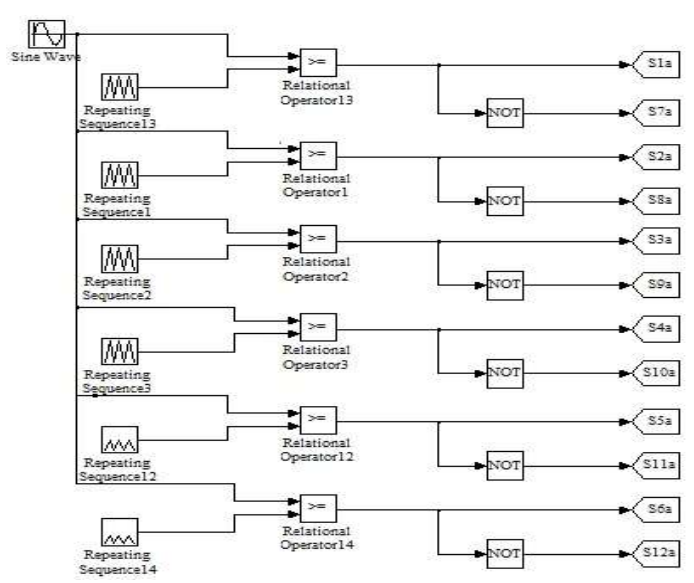

Figure 7. Model for gating signals of 7 level DCMLI using PD method

Figure 8 shows the simulation model using APOD method for generating gating signals in level generation stage of 7 level hybrid MLI. The simulation model for producing gating signals in polarity generation stage of 7 level hybrid MLI is shown in Figure 9.

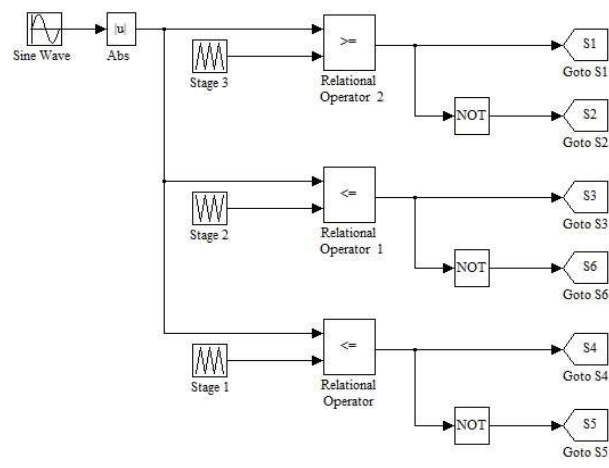

Figure 8. Model for gating signals in level generation part

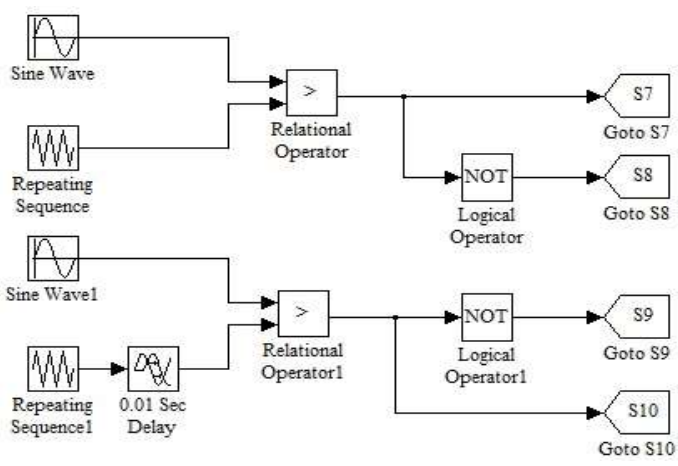

Figure 9. Model for gating signals in polarity generation part 


\section{RESULTS ANALYSIS}

The results obtained for DCMLI and hybrid MLI are eloberated for various loads. The performance of the inverters using LC filter are also discussed. The results obtained using APOD technique is presented below for 0.9 modulation index.

\subsection{DCMLI for 7, 9 and 11 levels}

The performance of DCMLI is shown below for various levels using different loads. The results of DCMLI for 7 levels are depicted in Figure 10 to Figure 12.

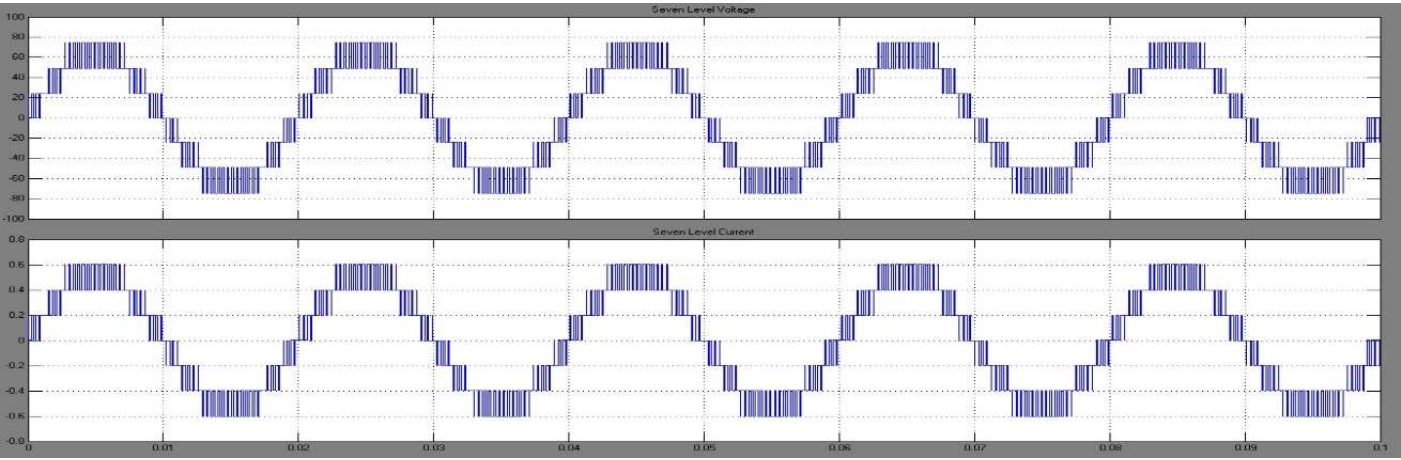

Figure 10. Waveforms of voltage and current in 7 level DCMLI for R load

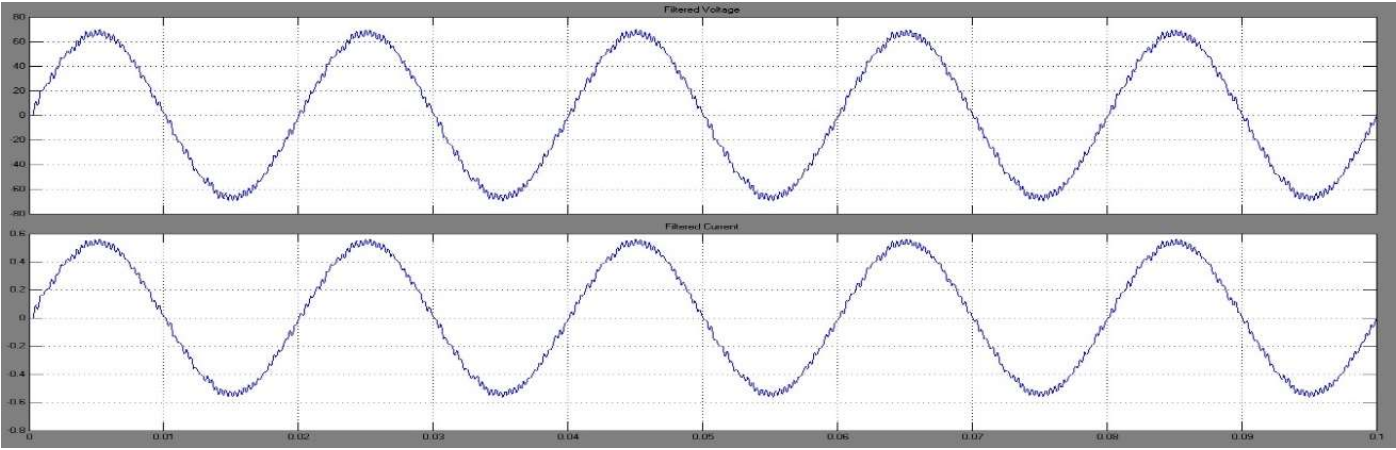

Figure 11. Waveforms of voltage and current in 7 level DCMLI for R load with filter

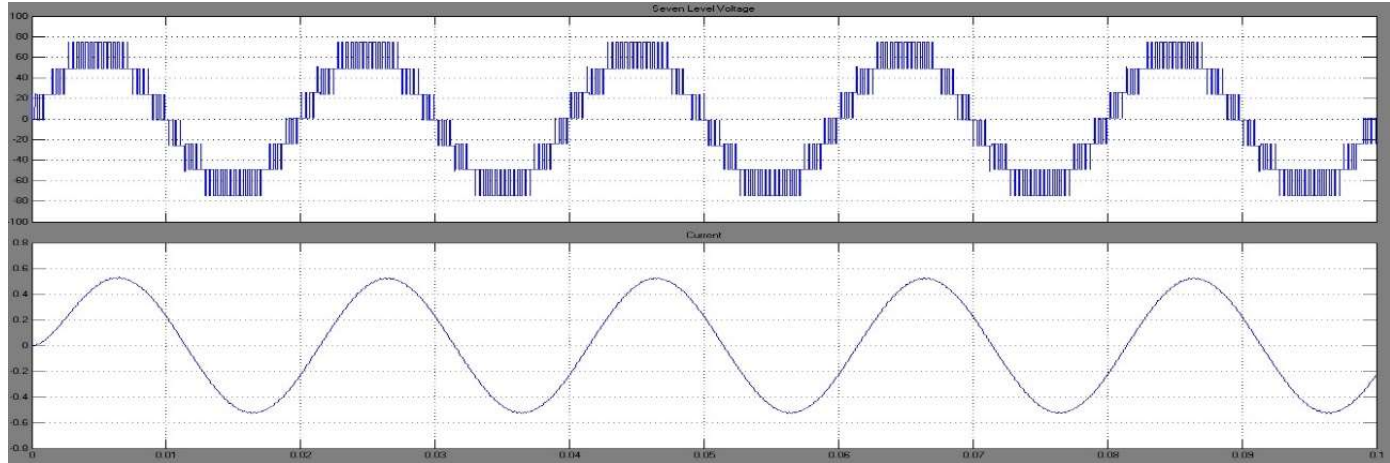

Figure 12. Voltage and current waveforms of 7 level DCMLI for R-L load 
The 9 level DCMLI results can be seen from Figure 13 to Figure 15 using APOD method. Figure 16 to Figure 18 presents the results of DCMLI for 11 levels.

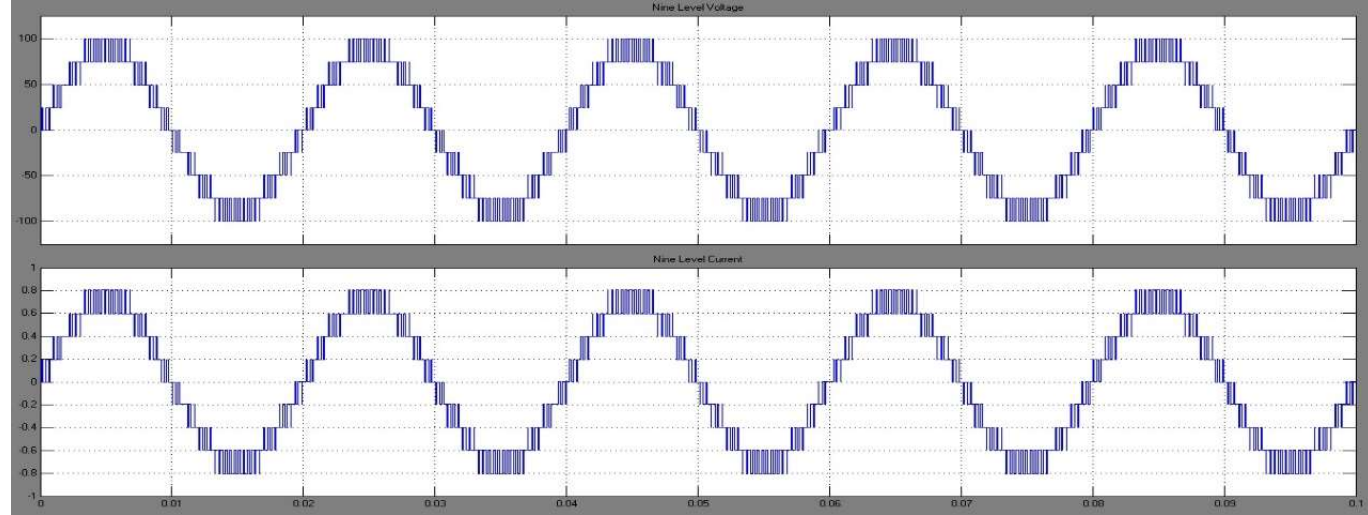

Figure 13. Waveforms of voltage and current in 9 level DCMLI for R load

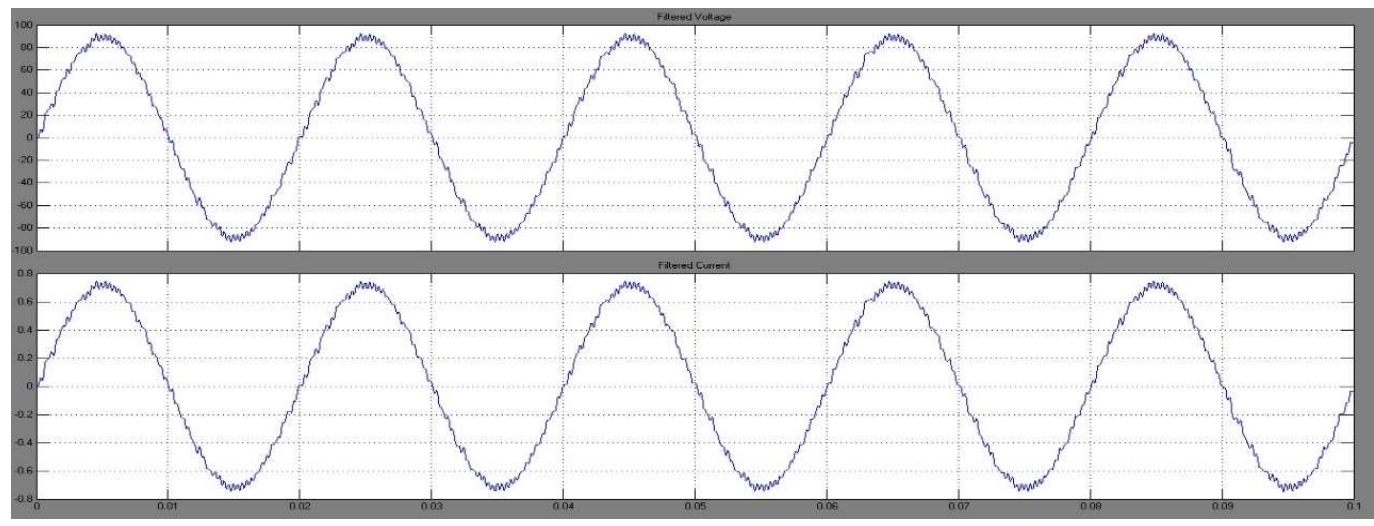

Figure 14. Waveforms of voltage and current in 9 level DCMLI for R load with filter

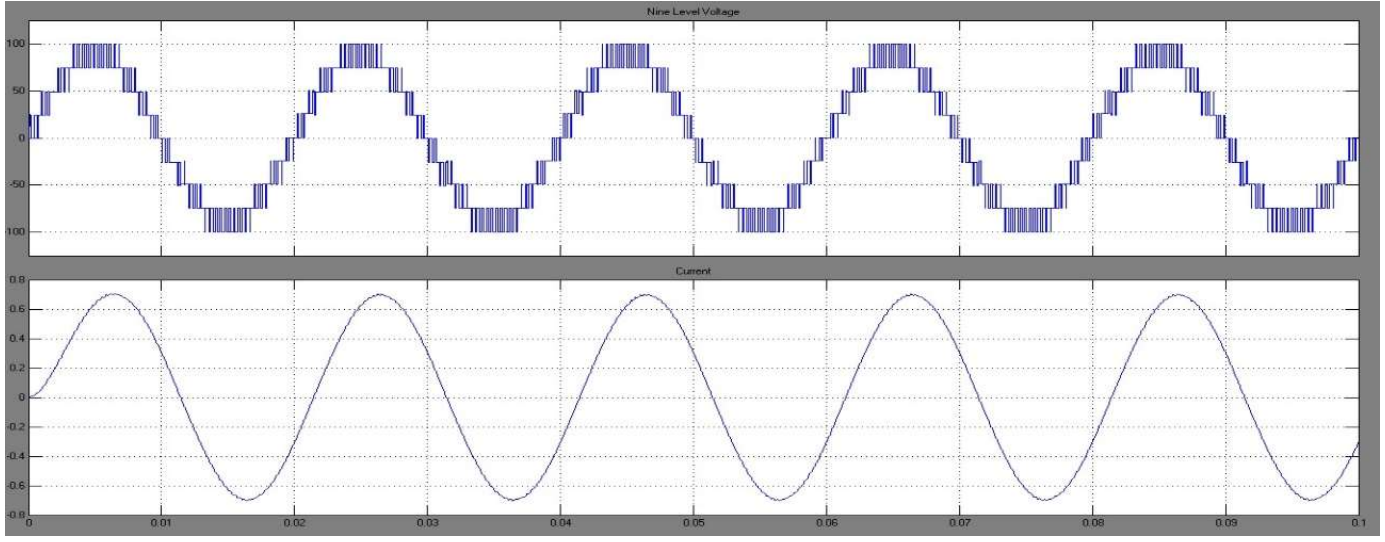

Figure 15. Waveforms of voltage and current in 9 level DCMLI for R-L load 


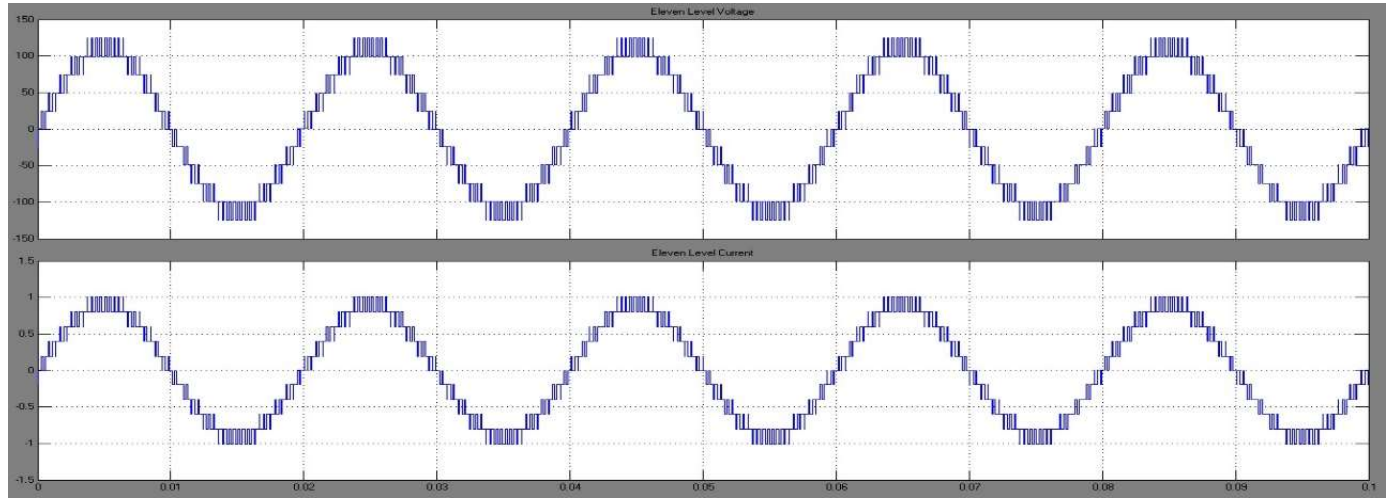

Figure 16. Waveforms of voltage and current in 11 level DCMLI for R load

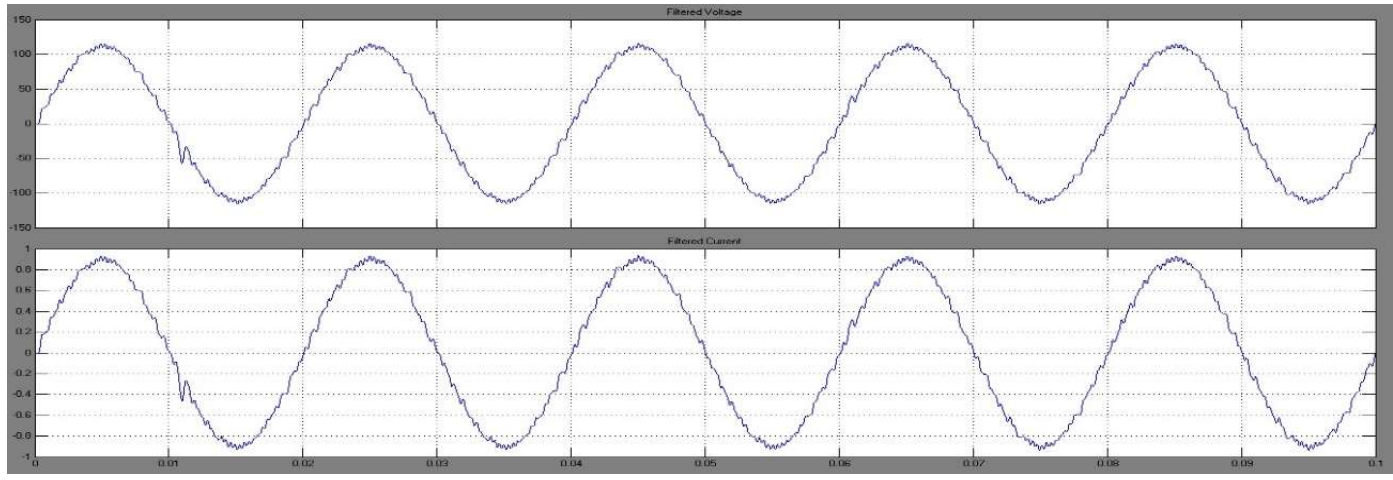

Figure 17. Waveforms of voltage and current in 11 level DCMLI for R load with filter

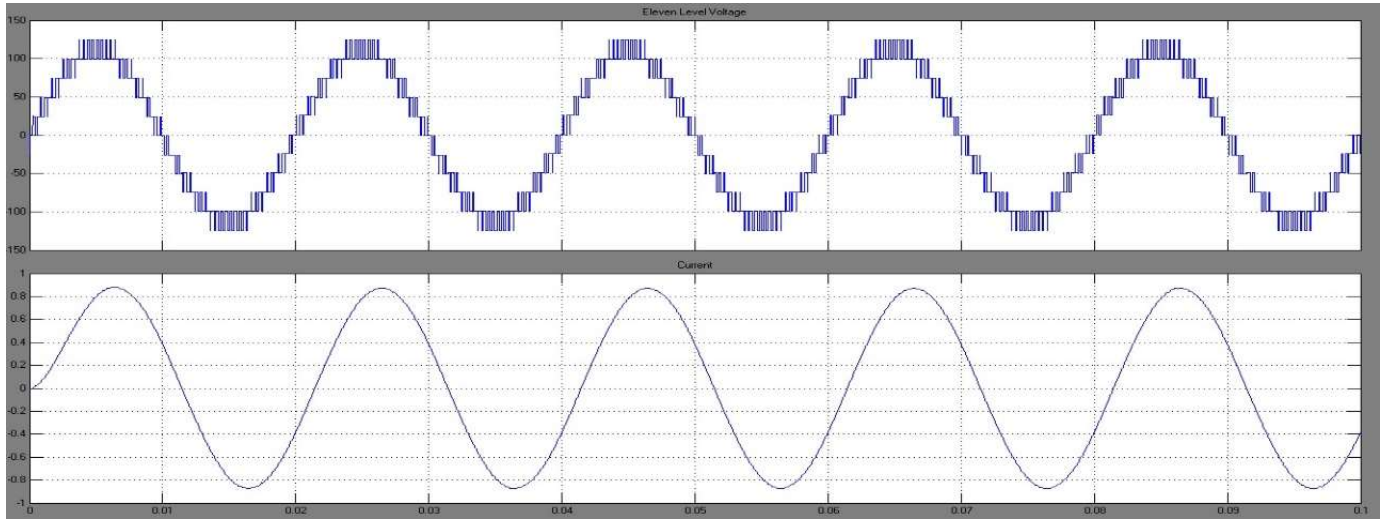

Figure 18. Waveforms of voltage and current in 11 level DCMLI for R-L load

\subsection{Hybrid MLI for 7, 9 and 11 levels}

The performance of hybrid MLI are presented in this section for various levels at different loads. Figure 19 to Figure 21 shows the results for single phase 7 level hybrid MLI. Whereas the results for single phase 9 level hybrid MLI are shown from Figure 22 to Figure 24. The waveforms obtained for single phase hybrid MLI are shown from Figure 25 to Figure 27 for 11 levels. 


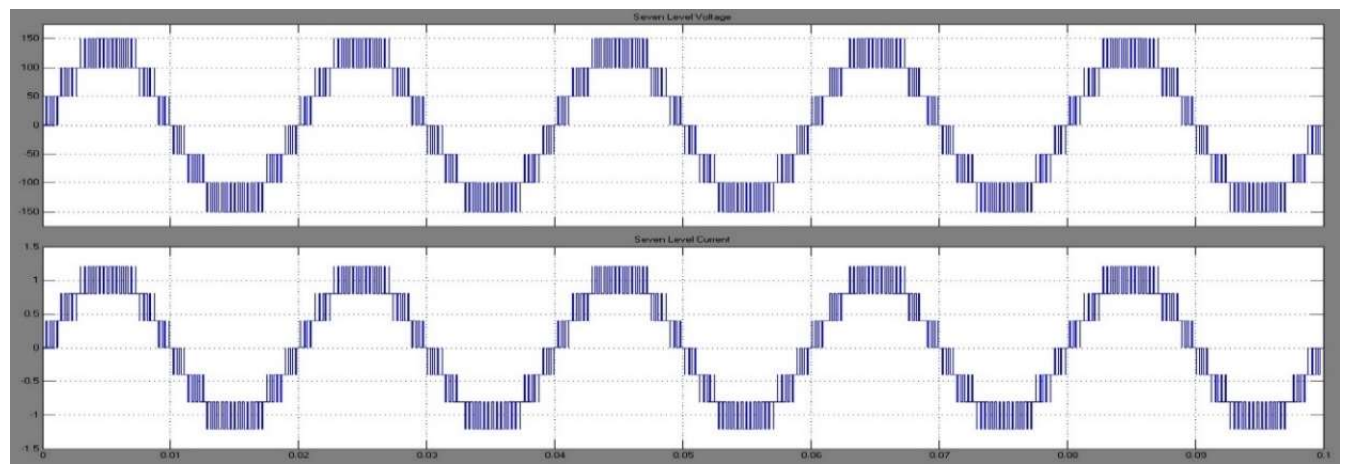

Figure 19. Waveforms of voltage and current in 7 level hybrid MLI for R load

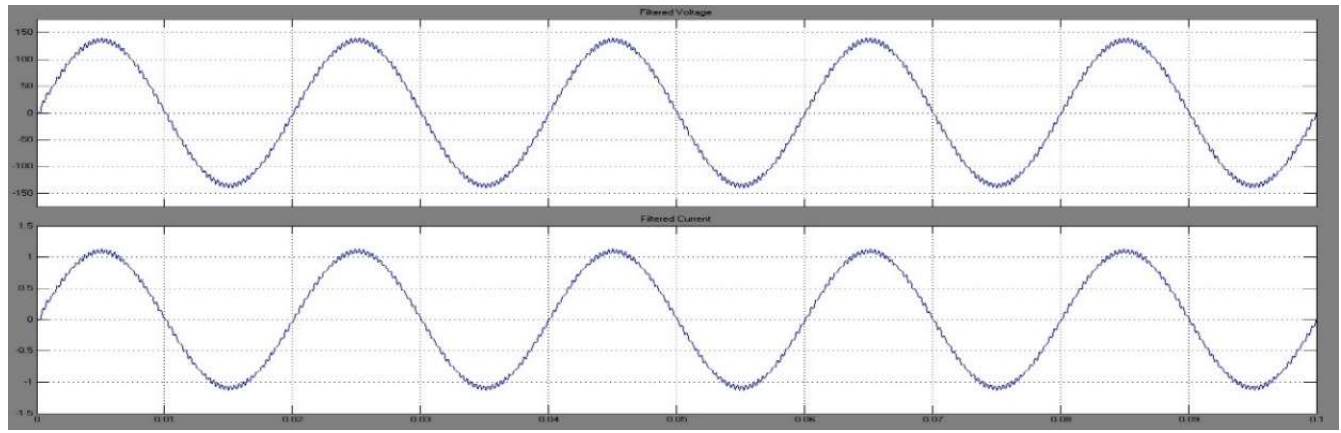

Figure 20. Waveforms of voltage and current in 7 level hybrid inverter for R load with filter

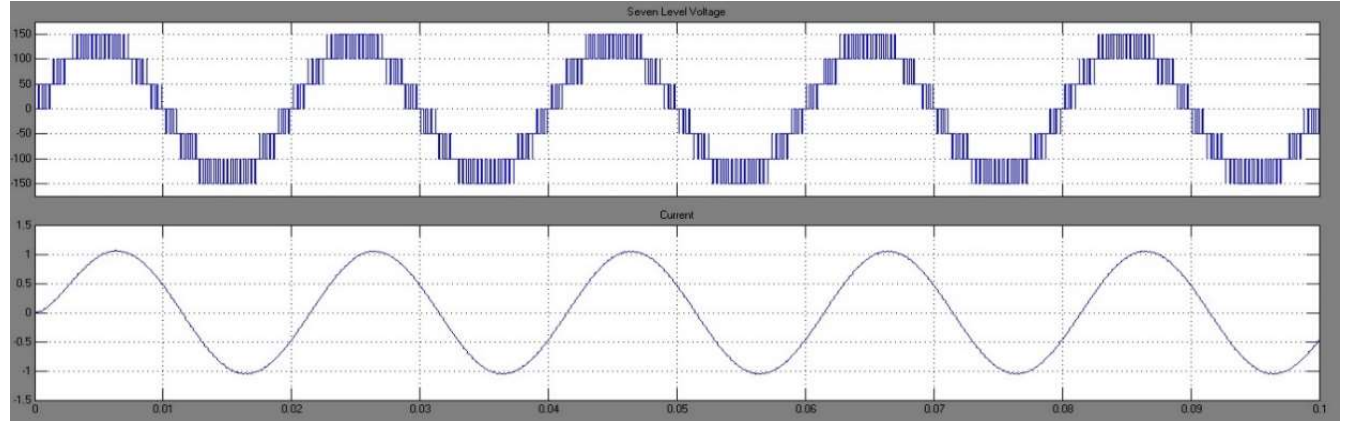

Figure 21. Waveforms of voltage and current in 7 level hybrid MLI for R-L load

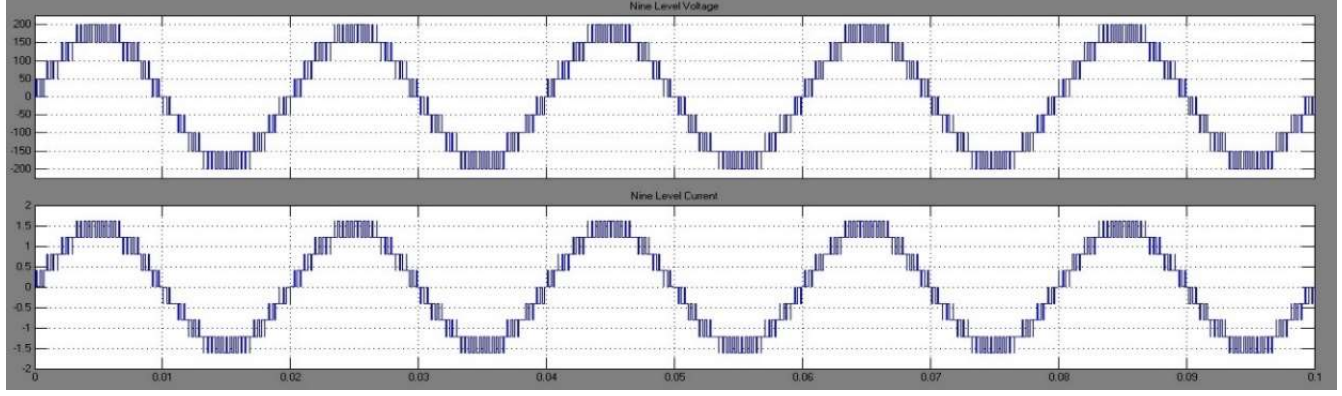

Figure 22. Waveforms of voltage and current in 9 level hybrid MLI for R load 


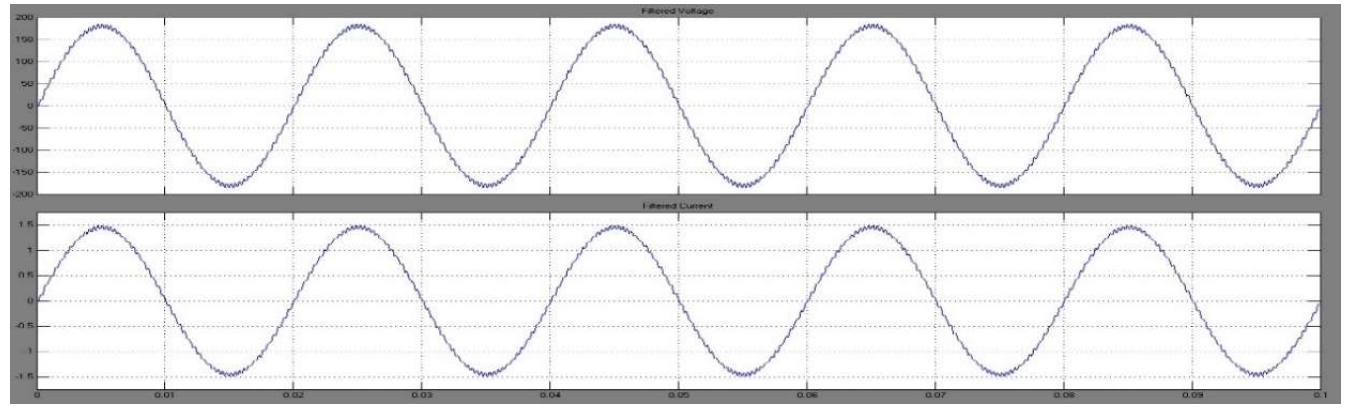

Figure 23. Waveforms of voltage and current in 9 level hybrid MLI for R load with filter

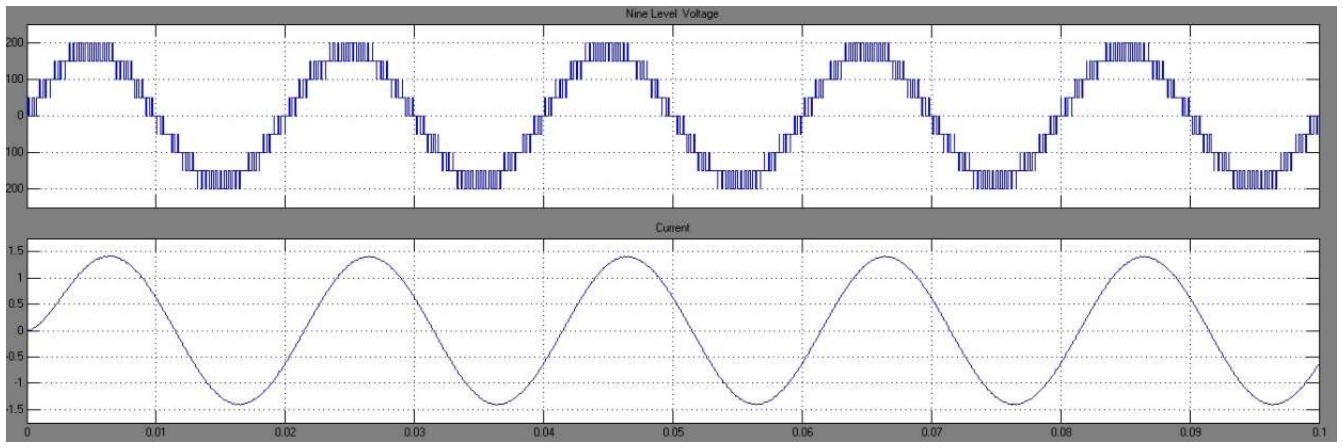

Figure 24. Waveforms of voltage and current in 9 level hybrid MLI for R-L load

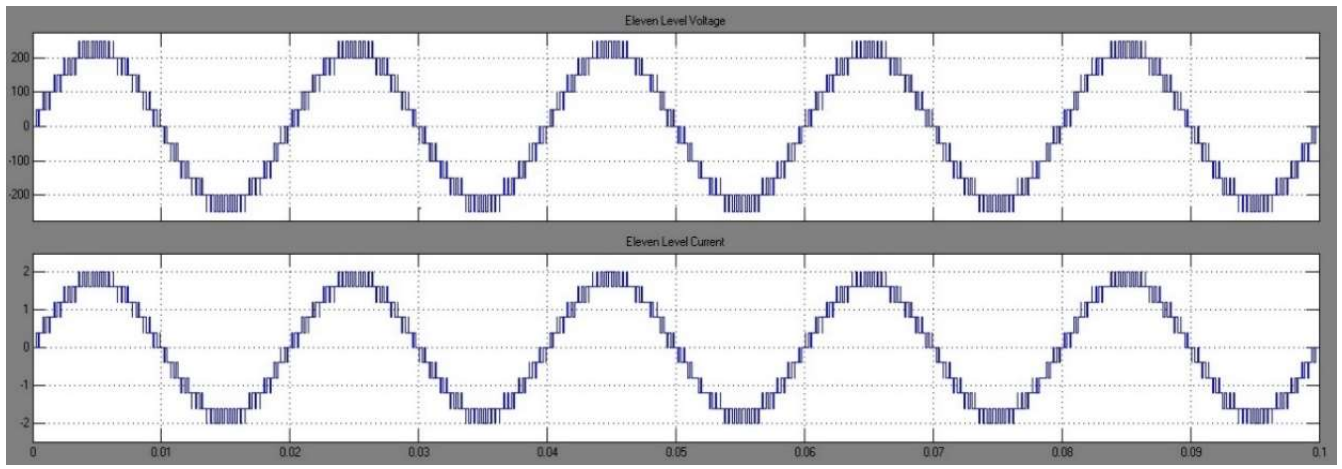

Figure 25. Waveforms of voltage and current in 11 level hybrid MLI for R load

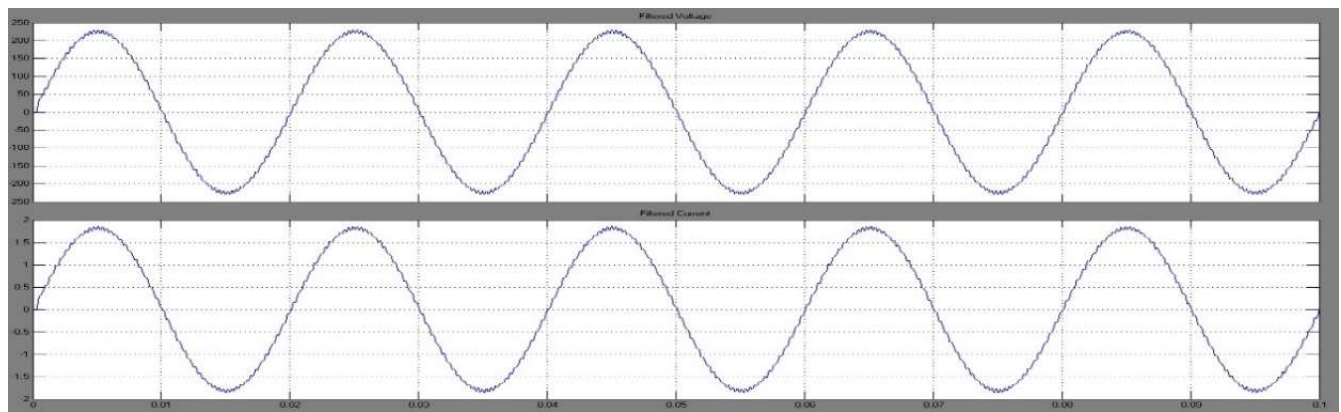

Figure 26. Waveforms of voltage and current in 11 level hybrid inverter for R load with filter

Perfomance evaluation and comparison of diode clamped multilevel inverter based... (N. Susheela) 


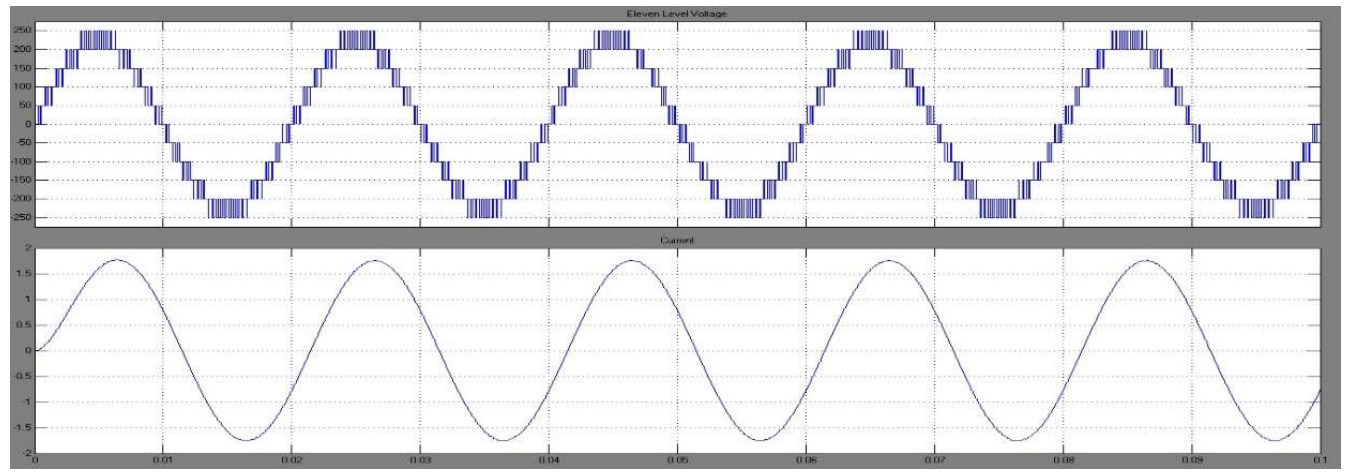

Figure 27. Waveforms of voltage and current in 11 level hybrid MLI for R-L load

\subsection{Comparison of DCMLI and hybrid MLI}

Table 1 to Table 3 summarizes the comparative analysis of single phase diode clamped MLI and hybrid MLI for seven, nine and eleven levels at various modulation indices $\left(\mathrm{m}_{\mathrm{a}}\right)$ using PD and APOD SPWM techniques. It is clear that the THD decreases as the modulation index is increased. At any level, the THD of hybrid inverter is less when compared to DCMLI. The THD is further reduced using LC filter.

Table 1. THD (\%) comparison using PD method for R load

\begin{tabular}{|c|c|c|c|c|c|}
\hline \multirow{2}{*}{$\begin{array}{l}\text { Number of } \\
\text { Levels }\end{array}$} & \multirow{2}{*}{$\mathrm{m}_{\mathrm{a}}$} & \multicolumn{2}{|c|}{ Without Filter } & \multicolumn{2}{|c|}{ Filter } \\
\hline & & DCMLI & Hybrid MLI & DCMLI & Hybrid MLI \\
\hline \multirow{4}{*}{7 level } & 0.85 & 18.67 & 12.29 & 3.97 & 1.13 \\
\hline & 0.9 & 17.52 & 11.48 & 3.83 & 1.05 \\
\hline & 0.95 & 15.77 & 11.08 & 3.53 & 1 \\
\hline & 1 & 13.97 & 9.84 & 3.28 & 0.92 \\
\hline \multirow{4}{*}{9 level } & 0.85 & 13.19 & 9.05 & 3.55 & 0.88 \\
\hline & 0.9 & 12.81 & 8.47 & 3.42 & 0.87 \\
\hline & 0.95 & 11.97 & 8.4 & 3.18 & 0.85 \\
\hline & 1 & 10.48 & 7.38 & 3.24 & 0.8 \\
\hline \multirow{4}{*}{11 level } & 0.85 & 10.02 & 7.15 & 2.5 & 0.79 \\
\hline & 0.9 & 10.11 & 6.8 & 2.84 & 0.8 \\
\hline & 0.95 & 9.54 & 6.65 & 2.57 & 0.83 \\
\hline & 1 & 8.25 & 6.05 & 3.12 & 0.77 \\
\hline
\end{tabular}

Table 2. THD (\%) comparison using APOD method for RL load

\begin{tabular}{cccccc}
\hline $\begin{array}{c}\text { Number of } \\
\text { Levels }\end{array}$ & $\mathrm{m}_{\mathrm{a}}$ & \multicolumn{2}{c}{ Without Filter } & \multicolumn{2}{c}{ Filter } \\
\hline & 0.85 & 18.5 & 12.21 & 3.18 & Hybrid MLI \\
\hline 7 level & 0.9 & 17.58 & 11.56 & 3.01 & 1.02 \\
& 0.95 & 15.74 & 11.12 & 2.93 & 0.99 \\
& 1 & 13.86 & 9.7 & 2.79 & 0.86 \\
9 level & 0.85 & 13.01 & 8.96 & 2.85 & 0.81 \\
& 0.9 & 12.88 & 8.53 & 2.7 & 0.8 \\
& 0.95 & 12.02 & 8.37 & 2.78 & 0.73 \\
11 level & 1 & 10.46 & 7.44 & 2.82 & 0.69 \\
& 0.85 & 9.77 & 7.34 & 2.54 & 0.71 \\
& 0.9 & 10.22 & 6.93 & 2.96 & 0.70 \\
\hline
\end{tabular}

Table 3. Current THD (\%) for R-L load

\begin{tabular}{|c|c|c|c|c|c|c|c|c|c|c|c|}
\hline \multicolumn{6}{|c|}{ PD method } & \multicolumn{6}{|c|}{ APOD method } \\
\hline \multicolumn{2}{|c|}{ 7-Level } & \multicolumn{2}{|c|}{ 9-Level } & \multicolumn{2}{|c|}{ 11-Level } & \multicolumn{2}{|c|}{ 7-Level } & \multicolumn{2}{|c|}{ 9-Level } & \multicolumn{2}{|c|}{ 11-Level } \\
\hline DCMLI & $\begin{array}{l}\text { Hybrid } \\
\text { inverter }\end{array}$ & DCMLI & $\begin{array}{l}\text { Hybrid } \\
\text { inverter }\end{array}$ & DCMLI & $\begin{array}{l}\text { Hybrid } \\
\text { inverter }\end{array}$ & DCMLI & $\begin{array}{l}\text { Hybrid } \\
\text { inverter }\end{array}$ & DCMLI & $\begin{array}{l}\text { Hybrid } \\
\text { inverter }\end{array}$ & DCMLI & $\begin{array}{l}\text { Hybrid } \\
\text { inverter }\end{array}$ \\
\hline 4.81 & 4.8 & 4.81 & 4.79 & 4.75 & 4.77 & 4.83 & 1.79 & 4.81 & 4.82 & 4.79 & 4.79 \\
\hline 4.81 & 4.83 & 4.79 & 4.81 & 4.77 & 4.75 & 4.81 & 4.79 & 4.82 & 4.82 & 4.78 & 4.79 \\
\hline 4.79 & 4.79 & 4.79 & 4.81 & 4.74 & 4.75 & 4.81 & 4.81 & 4.82 & 4.83 & 4.8 & 4.8 \\
\hline 4.79 & 4.77 & 4.8 & 4.79 & 4.76 & 4.79 & 4.81 & 4.71 & 4.81 & 4.83 & 4.78 & 4.78 \\
\hline
\end{tabular}

Int. J. of Adv. in Appl. Sci. Vol. 8, No. 2, June 2019: 143 - 153 


\section{CONCLUSION}

The single phase DCMLI and hybrid MLI are implemented for various levels at different modulation indices using PD and APOD SPWM control techniques. When compared to DCMLI, the hybrid MLI needs lesser number of high frequency switches for any number of levels. The hybrid MLI has many features compared to DCMLI in terms of the required switches, control requirements, cost, reliability and efficiency. The switches needed for various voltage levels for single phase hybrid MLI are lower compared to classical MLI's. The hybrid MLI can be preferred for applications like STATCOM, HVDC and FACTS. The low rated dc sources are required for hybrid MLI so the photovoltaic arrays and fuel cells can be utilized. The THD of DCMLI and hybrid MLI are analyzed at various modulation indices. It is observed that the THD reduces as there is an increase in modulation index. Different types of pulse width modulation control strategies can also be used to hybrid multilevel inverters.

\section{REFERENCES}

[1] Nabae, I. Takahashi and A. Akagi, “A new neutral-point clamped PWM inverter,” IEEE Trans. Ind. Appl., vol. 19, pp. 518-523, 1981.

[2] G. Mondal, K. Gopakumar, P. N. Tekwani, and E. Levi, "A reduced switch- count five-level inverter with commonmode voltage elimination for an open-end winding induction motor drive", IEEE Trans. Ind. Electron., vol. 54(4), pp. 2344-2351, 2007.

[3] P. M. Bhagwat and V. R. Stefanovic, "Generalized structure of a multilevel PWM inverter," IEEE Trans. Industry Applications, vol. 19(6), pp. 1057-1069, 1983.

[4] A. Rufer, "An aid in the teaching of multilevel inverters for high power applications," Proc. Rec. IEEE PESC'95, pp. 347-352, 1995.

[5] L. M. Tolbert, F. Z. Peng, and T. G. Habetler, "Multilevel converters for large electric drives," IEEE Trans. Ind. Appl., vol. 35(1), pp. 36-44, 1999.

[6] N. Susheela, P. Satish Kumar, and C. H. Reddy, "Performance Analysis of Four Level NPC and NNPC Inverters using Capacitor Voltage Balancing Method," IEEE Uttar Pradesh Section International Conference on Electrical, Computer and Electronics Engineering, Varanasi, pp. 212-217, 2016.

[7] G. Carrara, S. Gardella, M. Marchesoni, R. Salutari, and G. Sciutto, "A new multilevel PWM method: a theoretical analysis," IEEE Trans.Power Electronics., vol. 7(3), pp. 497-505, 1992.

[8] N. Susheela and P. Satish Kumar, "Performance Evaluation of Multicarrier Based Techniques for Single Phase Hybrid Multilevel Inverter using Reduced Switches," Indonesian Journal of Electrical Engineering and Computer Science, vol. 7, no. 3, pp. 676-686, September 2017.

[9] J. Rodriguez, J.-S. Lai, and F. Z. Peng, "Multilevel inverters: A survey of topologies, controls, and applications," IEEE Trans. Ind. Electron., vol. 49(4), pp. 724-738, 2002.

[10] E. Najafi, A. H. M. Yatim, and A. S. Samosir, "A new topology -Reversing Voltage (RV) - for multilevel inverters," IEEE $2^{\text {nd }}$ International Power, Energy Conference (PECon 08), pp. 604-608, 2008.

[11] S. A. Gonzalez, M. I. Valla, and C. F. Christiansen, "Analysis of a cascade asymmetric topology for multilevel converters," Proc. IEEE ISIE, pp. 1027-1032, 2007.

[12] N. Susheela and P. Satish Kumar, "Comparative Analysis of Carrier Based Techniques for Single phase Diode Clamped MLI and Hybrid Inverter with Reduced Components," Indonesian Journal of Electrical Engineering and Computer Science, vol. 7, no. 3, pp. 687-697, September 2017.

[13] E. Beser, B. Arifoglu, S. Camur, and E. K. Beser, "Design and application of a single phase multilevel inverter suitable for using as a voltage harmonic source", J. Power Electron., vol. 10(2), pp. 138-145, 2010.

[14] G. M. Martins, J. A. Pomilio, S. Buso, and G. Spiazzi, "Three-phase low frequency commutation inverter for renewable energy systems," IEEE Trans. Ind. Electron., vol. 53(5), pp. 1522-1528, 2006.

[15] Ehsan Najafi and Abdul Halim Mohamed Yatim, "Design and Implementation of a New Multilevel Inverter Topology," IEEE Transactions on Industrial Electronics, vol. 59(11), pp. 4148-4154, 2012.

[16] E. Babaei, "Optimal topologies for cascaded sub-multilevel converters," J. Power Electron, vol. 10, no. 3, pp. 251-261, 2010.

[17] C. Govindaraju and K. Baskaran, "Analysis and implementation of multiphase multilevel hybrid single carrier sinusoidal modulation,” J. Power Electron, vol. 10(4), pp. 365-373, 2010.

[18] R. Stala, "Application of balancing circuit for dc-link voltages balance in a single-phase diode-clamped inverter with two three-level legs," IEEE Trans. Ind. Electron, vol. 58(9), 4185-4195, 2011.

[19] N. Susheela and P. Satish Kumar, "Performance Analysis of FPGA based Diode Clamped Multilevel Inverter Fed Induction Motor Drive using Phase Opposition Disposition Multicarrier Based Modulation Strategy," International Journal of Power Electronics and Drive System (IJPEDS), vol. 8, no. 4, pp. 1512-1523, December 2017. 